\title{
ANNA KiBYCZ
}

Uniwersytet im. J. Fedkowycza w Czerniowcach, Ukraina

\section{Uwarunkowania rozmieszczenia usług turystycznych na Huculszczyźnie}

Huculszczyzna to region położony w zachodniej części Ukrainy o wybitnie górskim charakterze krajobrazu, zamieszkany przez ludność, którą nadal cechuje tradycyjny styl życia i wytwórczości. Na skutek ograniczonej dostępności przestrzennej i silnej tożsamości etnicznej Hucułów (górali pochodzenia ruskiego i wołoskiego) region ten jest unikatowym przykładem zachowania tradycji i kultury i pozostaje nadal jednym z najmniej ucywilizowanych obszarów Karpat (Stahl 2001).

Walory przyrodnicze, antropogeniczne i kulturowe same w sobie nie są jednak współcześnie wystarczającym powodem, dla którego wzrośnie ruch turystyczny. Jest to zaledwie baza, na której powinna rozwinąć się infrastruktura turystyczna. Jej funkcjonowanie oparte w dużej mierze na szeroko pojętym sektorze usług, w tym usług turystycznych, powinno stać się jedną z najważniejszych atutów regionu. Istotny jest przy tym nie tylko poziom, profesjonalizm świadczonych usług, ale również odchodzenie od szablonowości, swoista oryginalność połączona z modą na etniczność.

Celem artykułu jest ukazanie ogólnych uwarunkowań przyrodniczych i historyczno-kulturowych determinujących usługi turystyczne na Huculszczyźnie.

Położenie geograficzne, jako jedna z cech obiektu geograficznego, jest często tym elementem, który decyduje o pozostałych, nakładających się na siebie cechach przyrodniczych, społecznych i gospodarczych. Tak jest również w tym przypadku.

Przyrodniczo Huculszczyzna położona jest w Karpatach Wschodnich i obejmuje południowowschodnią najwyższą część Karpat Ukraińskich ( z kulminacją na wysokości $2061 \mathrm{~m}$ n.p.m. - szczyt Howerla) w dorzeczu rzek Bystrzyca Nadwórniańska, Prut, Cisa, Czeremosz. Ukraińska część zajmuje powierzchnie 5,2 tys. $\mathrm{km}^{2}$, co stanowi $80 \%$ powierzchni ogólnej etnoregionu ${ }^{1}$. Jej obszar nie zawiera się jednak w całości w granicach Ukrainy, gdyż południowa część położona jest w Karpatach Rumuńskich w górnym biegu rzek Cisa, Mołdawica i Suczawa. Pod względem społeczno-gospodarczym ukraińska część dzieli się na trzy historyczno-geograficzne części: galicyjską - w granicach obwodu Iwano-Frankowskiego (53\% powierzchni), zakarpacką - granicach obwodu Zakarpackiego (30\% powierzchni), bukowiński - w granicach obwodu Czerniowieckiego (17\% powierzchni), (ryc. 1).

1 Etnoregion - obszar zamieszkiwany przez grupę etniczną z wyraźnie wyodrębnioną, symboliczną sferą identyfikacyjną dotyczącą miejsca i przestrzeni (Rossa-Kilian 2008). 


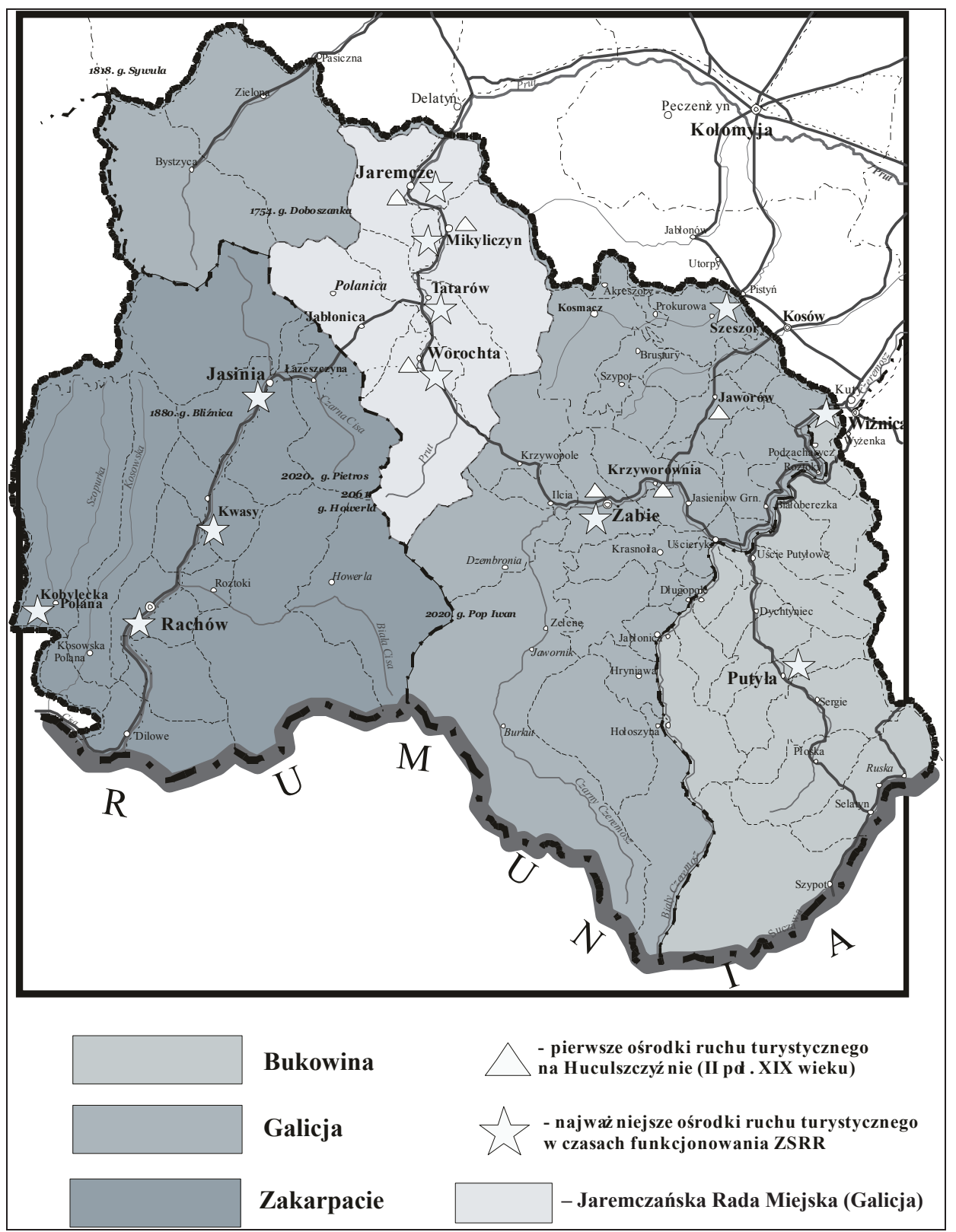

Ryc. 1. Najważniejsze ośrodki ruchu turystycznego na Huculszczyźnie Źródło: opracowanie własne na podstawie Ławruk 2005

Położenie Huculszczyzny wydaje się sprzyjać nie tylko turystyce, ale także transgranicznej, ekonomicznej i kulturalnej współpracy z Hucułami Marmaroszczyzny i południowej Bukowiny zamieszkującymi Rumunię. Nie bez znaczenia jest również administracyjna 
przynależność Huculszczyzny do przygranicznych obwodów Ukrainy, dzięki czemu istnieje realna możliwość kontaktów nie tylko z Rumunią, ale i z Węgrami, Słowacją, Polską oraz Mołdawią.

Znaczący wpływ na rozwój Huculszczyzny miał i ma nadal niski potencjał ekonomiczny tego regionu, słaba integracja gospodarki z resztą kraju, nierozwinięta komunikacja drogowa i kolejowa, podział polityczno-administracyjny, niekorzystna struktura zatrudnienia według sektorów gospodarki, z niską liczbą pracujących w sektorze usługowym. Mimo to w ostatnich latach cały obszar Karpat Ukraińskich, a z nim i Huculszczyzna, zyskał na atrakcyjności turystycznej. Przyczyny tego leżą jednak po stronie popytowej (wzrost zamożności potencjalnych turystów), a nie po stronie podażowej, gdzie mimo kilkunastu prywatnych inwestycji ciagle widoczny jest duży niedobór w zasadzie wszystkich elementów zagospodarowania turystycznego (baza noclegowa, baza żywieniowa, baza rekreacyjna, baza wspomagająca).

W strukturze przyjeżdżających obserwuje się przewagę turystów krajowych, tym samym w pierwszej kolejności nasyca się zgłaszany popyt wewnętrzny. Sygnalizowany już wzrost zamożności Ukraińców powoduje ich napływ na krajowe tereny atrakcyjne turystycznie, ponieważ z racji uwarunkowań prawnych oraz umów międzynarodowych nie mogą bez przeszkód korzystać np. z kurortów europejskich. Jednocześnie istniejący poziom i jakość świadczonych usług turystycznych nie jest specjalnie atrakcyjny dla turystów zagranicznych. Wpływ na wielkość ruchu turystycznego na Huculszczyźnie mają ponadto coraz doskonalszy system promocji turystycznej (z wykorzystaniem Internetu), rosnący poziom bezpieczeństwa oraz moda na turystykę etniczną.

Jak wynika z ustaleń autorki, wpływ na dalsze kształtowanie usług turystycznych na Huculszczyźnie mają: położenie geograficzne, ład i poziom zagospodarowania przestrzennego regionu, uwarunkowany historycznie układ sieci osadniczej (jej osobliwość), poziom rozwoju infrastruktury turystycznej oraz transportowej.

Klimatyczne i estetyczne walory huculskiego śródowiska przyrodniczego doceniono już na początku XVIII w. Pierwsze ośrodki turystyczne powstały w XIX w. w części galicyjskiej, a zwłaszcza w Żabie, Krzyworówni, Jaremczy, Worochcie, Mikuliczynie, Burkucie i Jaworowie (ryc. 1). Warto jednak podkreślić, że aktywność ówczesnych turystów ograniczała się do wynajmowania u Hucułów pokoi i zakupu miejscowych tradycyjnych artykułów spożywczych. Turystami byli przede wszystkim Polacy, Niemcy i Rosjanie, czasem ukraińskiego pochodzenia, głównie inteligencja (Grabowiecki 1995). W XIX w. w czasach monarchii austro-węgierskiej realizowano pierwotne formy turystyki, dla celów turystyki adaptowano pasterskie bacówki, a pasterze stawali przewodnikami górskimi (Nesteruk, Rożko 1997). Rozwijający się ruch turystyczny i popularność Huculszczyzny w okresie II Rzeczpospolitej spowodowały, iż w 1937 r. utworzono Czarnohorskie Ochotnicze Pogotowie Ratunkowe, będące górską służbą ratowniczą z siedzibą w Worochcie (Pagacz, Pagacz 2004).

W okresie Związku Radzieckiego infrastruktura turystyczno-rekreacyjna Huculszczyzny nabrała cech gigantomanii - dominowały zorganizowane formy odpoczynku w wielkim kompleksach turystycznych. Były to zwykle wielkie domy wczasowe i sanatoria w miejscowościach z dobrym połączeniem transportowym (kolejowym), dzięki czemu można było w sposób zorganizowany dowozić grupy turystów. Niestety poziom wyposażenia obiektów był niski. $\mathrm{Z}$ tego okresu pochodzi materialno-techniczna baza infrastruktury, zlokalizowana zwykle w małych miastach regionu. Były to: Jaremcza, Rachów, Worochta, Werchowina (Żabie), Putyła i inne Wśród nich dominującą rolę pełniła Jaremcza, która dzięki swojej 
bazie noclegowej i żywieniowej mogła przyjąć rocznie do półtora miliona turystów (Ławruk 2005).

Turystyka zbiorowa nie wyeliminowała całkowicie turystyki indywidualnej, w tym agroturystyki. Tego typu formy wypoczynku były nadal uprawiane, szczególnie przez inteligencję, jednak na znacznie mniejszą skalę. W okresie 1945-1991 turystyka była realizowana w sposób planowy i centralnie kierowana. Nie sprzyjało to zaspokajaniu potrzeb ludności miejscowej, chociaż w sposób dość przypadkowy, spontaniczny i mało efektywny przyczyniło się do rozwoju sieci osadniczej, produkcji artykułów spożywczych i produkcji pamiątkarskiej.

$\mathrm{Na}$ początku lat 90 ., w okresie przemian politycznych i w efekcie uzyskania przez Ukrainę niepodległości, dotychczasowa baza turystyczno-rekreacyjna Huculszczyzny stała się niewydolna, a jej funkcjonowanie nieuzasadnione ekonomicznie. Przyczyną tego był przede wszystkim spadek zamożności Ukraińców i obywateli państw powstałych po rozpadzie Związku Radzieckiego oraz zerwanie dotychczasowych powiązań między ośrodkami turystycznymi a zakładami pracy, które znalazły się poza granicami Ukrainy. Pierwsze oznaki wychodzenia z recesji pojawiły się już pod koniec lat 90., nastąpiła wówczas względna stopniowa stabilizacja gospodarki, a w konsekwencji wzrost popytu na usługi turystyczne. Jednocześnie dzięki pierwszym inwestycjom w turystykę sektora prywatnego wzrosła zdolność konkurencyjna branży. Ich ilość okazała się jednak niewystarczająca, a poziom obsługi relatywnie niski, przez co na Huculszczyźnie zaczęła rozwijać się agroturystyka. Pod koniec lat 90. łączna liczba gospodarstw agroturystycznych szacowana była na 50-100 (Ławruk 2005).

Jak wynika z współcześnie przyjmowanych strategii, pożądanym kierunkiem procesu rozwoju społeczno-gospodarczego Huculszczyzny jest turystyka, a zwłaszcza rekreacyjne wykorzystanie przyrody poprzez kontrolowaną rozbudowę infrastruktury turystyczno-rekreacyjnej. Niestety nie ma wspólnej, jednolitej polityki zagospodarowania przestrzennego dla całej Huculszczyzny, ponieważ na skutek podziału administracyjnego kraju została ona wcielona w trzy różne obwody, których priorytety rozwoju zostały różnie określone.

Najważniejsze, a jednocześnie jedyne dostępne dane charakteryzujące współczesną podstawową infrastrukturę turystyczną dotyczą bazy noclegowej, w szczególności noclegowych usług hotelarskich. Usługi tego typu są oferowane przez różne grupy obiektów.

Do pierwszej można zaliczyć poradzieckie turbazy. Cechuje je kolektywna forma własności (spółki akcyjne). Ich standard jest bardzo zróżnicowany. Obok starych radzieckich wnętrz pojawiają się obiekty całkowicie zmodernizowane. Takie kompleksy hotelowe są zazwyczaj bardzo pojemne, nierzadko pracuje w nich „stara kadra”, która ciężko adaptuje się do wymagań współczesnego turysty. Być może dlatego najczęściej te turystyczne uzdrowiskowe kompleksy obsługują dzieci i młodzież szkolną, czyli najmniej wymagającą grupą konsumentów usług turystycznych.

Druga grupa obiektów to hotele nowej generacji zbudowane według po $1990 \mathrm{r}$. według europejskich standardów architektonicznych i technicznych, oferujące wysoką jakość obsługi klienta. Zazwyczaj to mini-hotele do 50 miejsc noclegowych, o indywidualnym wystroju, często odwołującym się do motywów huculskich, których właściciel poza noclegami oferuje szeroką gamę usług dodatkowych (np. wycieczki po okolicy).

Trzecia grupa obiektów to intensywnie rozwijające się to gospodarstwa agroturystyczne. Tego typu forma wypoczynku jest szczególnie popularna wśród turystów krajowych, ale rośnie tez liczba turystów zagranicznych. Huculski agroturyzm daje nie tylko możliwość 
wypoczynku za niską cenę, ale również pozwala na obcowanie z autentyczną miejscową kulturą (Bundziak 2005).

Warto zaznaczyć, że agroturystyka może być realizowana również w miastach regionu, ponieważ ich wielkość, funkcje w sieci osadniczej, a nade wszystko warunki ekologiczne mało różnią się od obszarów wiejskich. Największy potencjał dla rozwoju agroturystyki (pod względem krajobrazowym, osadniczym oraz kulturowym) ma wschodnia część Huculszczyzny w ramionach rzek Czeremosz i Prut (Galicja i Bukowina). Niska gęstość zaludnienia, dużo niezabudowanej przestrzeni (górskie łąki i lasy), malownicze krajobrazy, rozwinięta gospodarka pastwiskowa i rzemiosło artystyczne są tam dobrą podstawą dla agroturystyki.

Baza żywieniowa na Huculszczyźnie rozwinięta dzięki animacji ruchu turystycznego to głównie przyhotelowe restauracje, kawiarnie i bary, ulokowane w największych popularnych miejscowościach turystycznych oraz niewielkie wiejskie lokale gastronomiczne. Powoduje to, że rozmieszczenie przestrzenne bazy żywieniowej na Huculszczyźnie jest mocno zróżnicowane (ryc. 2, 3, 4).

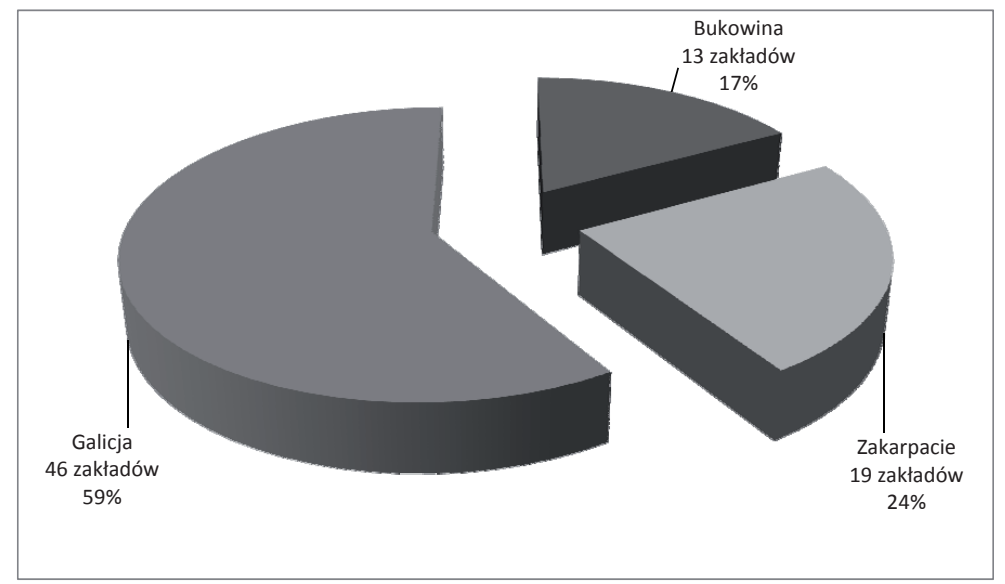

Ryc. 2. Baza żywieniowa na Huculszczyźnie (stan na VI 2009 r.)

Źródło: opracowanie własne na podstawie niepublikowanych danych statystycznych z Urzędów Statystycznych w Czerniowcach i Jaremczy

Wielkie znaczenie dla turystyki na Huculszczyźnie ma układ komunikacyjny. Niedostateczna sieć dróg i ich kiepska jakość nie dają gwarancji dynamicznego rozwoju w najbliższym czasie. Na początku XXI w. Huculszczyzna ma najmniejszą w Karpatach Ukraińskich sieć dróg utwardzonych. Przy niesprzyjających warunkach meteorologicznych do wielu miejsc nie można dojechać. Zadowalające pod względem stanu i utrzymania są zaledwie cztery trasy samochodowe: krajowa, łącząca Przykarpacie z Zakarpaciem przez Przełęcz Jabłonicką oraz trzy lokalne łączące miasta przykarpackie z Putyłą, Wierchowiną i Worochtą (Lawruk 2005).

Drugim rodzajem transportu publicznego jest kolej. Przez całe terytorium Huculszczyzny przechodzi zaledwie jedna linia kolejowa trakcji spalinowej łącząca Galicję i Zakarpaciem. Umożliwia to przejazd ze Lwowa i Iwano-Frankowska przez Kołomyję do najbardziej znanych ośrodków turystycznych regionu, w tym do Jaremczy, Mikuliczyna, Tatarowa, Worochty, Łazeszczyny, Jasini, Rachowa. Jak wspomniano wyżej, rozkład przestrzenny ru- 
chu turystycznego jest bardzo zróżnicowany. Największą dynamiką rozwoju podstawowej infrastruktury turystycznej charakteryzuje się Galicja. Decydują o tym takie czynniki, jak uwarunkowanie historyczne i poziom rozwoju infrastruktury transportowej, ponieważ właśnie przez tę część regionu przechodzą najważniejsze szlaki komunikacyjne.

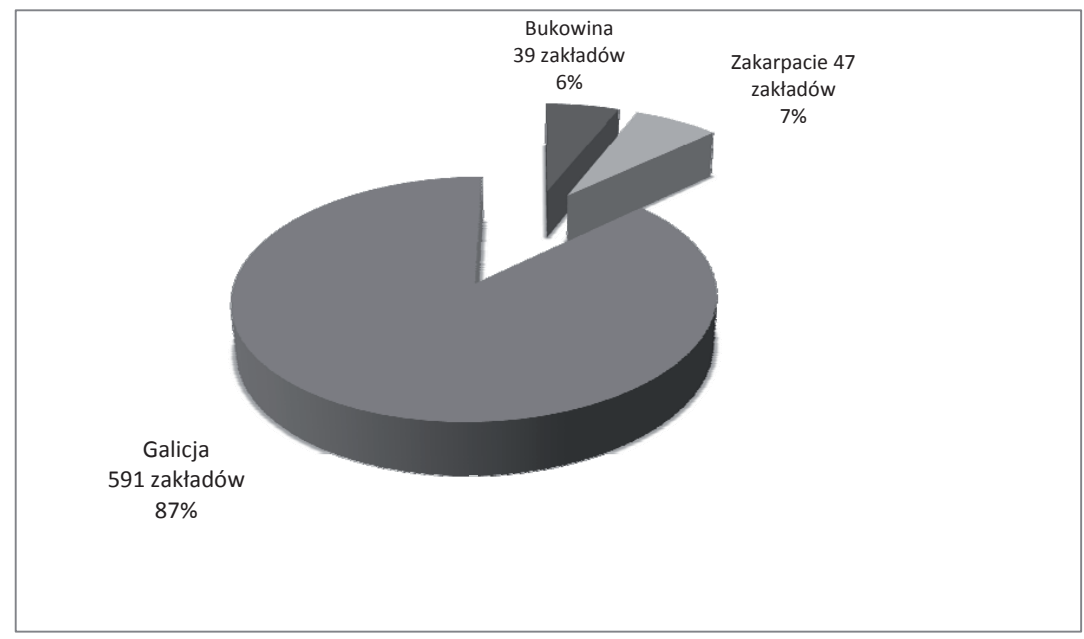

Rys. 3. Baza noclegowa Huculszczyzny (stan na VI 2009 r.)

Źródło: opracowanie własne na podstawie niepublikowanych danych statystycznych z Urzędów Statystycznych w Czerniowcach i Jaremczy

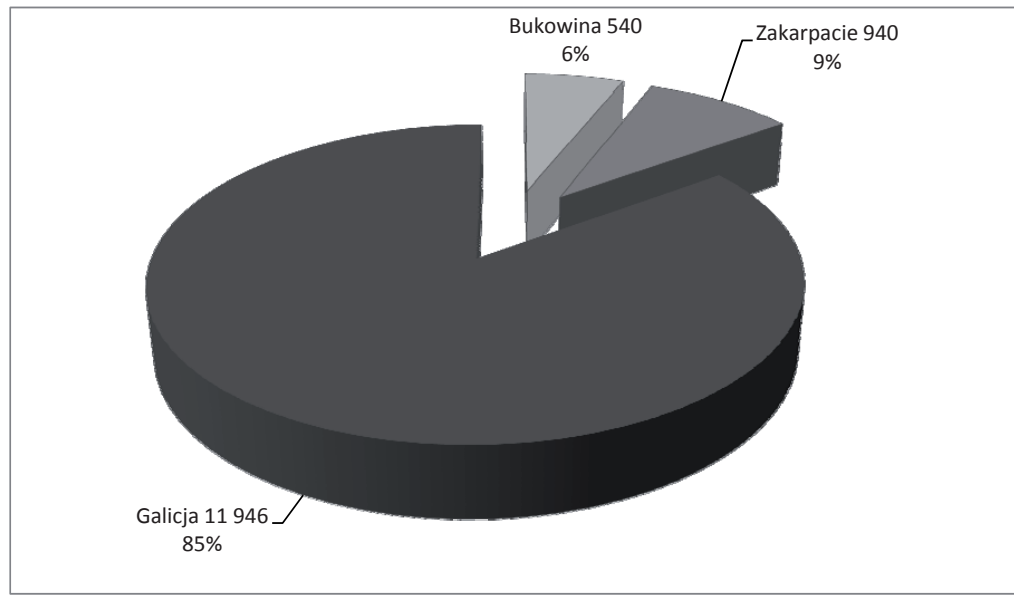

Rys. 4. Liczba miejsc noclegowych na Huculszczyźnie (stan na VI 2009 r.)

Źródło: opracowanie własne na podstawie niepublikowanych danych statystycznych z Urzędów Statystycznych w Czerniowcach i Jaremczy

Najlepsze warunki dla rozwoju turystyki obserwuję się na terytorium podlegającym Jaremczańskiej Radzie Miejskiej (ryc. 1). Wynika to z faktu, że na jej terytorium znajduje się Karpacki Park Narodowy, z najwyższym szczytem Ukrainy Howerlą. Ponadto właśnie tutaj, na zboczu Polanicy (850-1372 m n.p.m.) znajduje się najpopularniejszy na Ukrainie narciarski kurort Bukowel. Tu znajduje się 68\% bazy noclegowej i $81 \%$ miejsc noclegowych 
regionu, a wielkość ruchu turystycznego tylko w okresie od maja do sierpnia 2009 r., określona na 203,1 tys. turystów, stanowiła 85\% ogółu. Sukces turystyki na omawianym obszarze związany jest nie tylko z krajobrazem i walorami przyrodniczymi, ale także z zakrojonymi na szeroką skalę działaniami marketingowymi.

Obecnie kierunek rozwoju turystki na Huculszczyźnie oparty jest przede wszystkim na promowaniu walorów przyrodniczych związanych z potencjałem geograficznym Karpat. Ponadto w perspektywie strategicznej za istotne przyjmuje się skuteczniejsze i pełniejsze wykorzystanie jako atrakcji turystycznej oryginalnej kultury ukraińskich górali w połączeniu $\mathrm{z}$ dążeniem do wypracowania standardów ekologicznych w regionie. Nie może to jednak odbyć się bez poważniejszych inwestycji w infrastrukturę turystyczną oraz komunikacyjna.

Reasumując, można wysnuć następujące wnioski. Po pierwsze, rozmieszczenie podstawowej infrastruktury turystycznej na Huculszczyźnie ma nadal wyraźne przesłanki historyczne (np. Jaremcza), jednakże rośnie rola obiektów uruchomionych w niepodległej Ukrainie, np. Polanica, Jabłonica. Po drugie, rozbudowa infrastruktury następuje w bezpośrednim sąsiedztwie najbardziej atrakcyjnych miejsc pod względem przyrodniczym (np. Worochta i Łazeszczyna - góra Howerla) i etnicznym (Kosmacz - wieś o najlepiej zachowanych tradycjach na Huculszczyźnie). Po trzecie, rozkład przestrzenny obiektów podstawowej infrastruktury przestrzennej jest bardzo zróżnicowany. Dominującą rolę odgrywa Galicja. Po piąte, rozbudowa już istniejącej infrastruktury oraz budowa nowych obiektów jest silnie skorelowana dodatnio z poziomem atrakcyjności na obszarze Huculszczyzny, np. Jaremcza. Werchowina (Żabie). Po szóste, obszar administracyjny Jaremczańskiej Rady Miejskiej pełni wiodącą rolę w obsłudze ruchu turystycznego - skupia większość obiektów podstawowej infrastruktury turystycznej regionu.

Wszystkie powyższe przesłanki mają znaczenie dla rozwoju turystyki i rekreacji na Huculszczyźnie, jednak warto podkreślić, że rośnie zdecydowanie rola czynnika historyczno-etnograficznego, który łączony jest często z szukaniem tożsamości narodowej i kulturowej nie tylko rdzennych mieszkańców, ale Ukraińców w ogóle. Na tym kapitale budowana jest współczesna infrastruktura turystyczna, która koncertuje się przede wszystkim w uznanych ośrodkach etnograficznych i zwykle orientowana jest na etnoturystów.

\section{Literatura}

Bundziak J., 2005, Wpływ turystycznej działalności na etnicznq tożsamość ukraińskich góralej, [w:] Ekologiczne ta społeczno-ekonomiczne aspekty zachowania etnokulturnej i historycznej spuścizny Karpat, Materiały międzynarodowej naukowo-praktycznej konferencji, red. F. Gamor, Rachów, s. $154-158$.

Grabowiecki W., 1995 Narys historii Przykarpacia. Huculszczyzna w drugiej polowie XIX-pocz. XX wieku, Iwano-Frankowsk, t. 8.

Dziewierski M., Nawrocki T. (red.), 1997, Grupa etniczna, region, tożsamość kulturowa, Wydawnictwo Uniwersytetu Śląskiego, Katowice.

Ławruk M., 2005, Huculi Ukraińskich Karpat, Wydawnictwo Uniwersytetu Lwowskiego, Lwów.

Nesteruk J., Rożko I., 1997, Z historii rekreacyjnego przyrodokorzystania w Chornohorze ta drogi jego optymalizacji w współczesnych umowach, [w:] Z historii turystyki ojczystej. Zbornik artykułów, Kijów, s. 184-185

Pagacz J., Pagacz S., 2004, Ukraina: Huculszczyzna, Podróże, nr 11 (77).

Rossa-Kilian D., 2008, Struktura etniczno-kulturowa regionu Morza Bałtyckiego, Zeszyty Naukowe Akademii Marynarki Wojennej, Gdynia. 
Stahl B., 2001, Dawne Pokucie i Huculszczyzna w opisach cudzoziemskich podróżników. Wybór tekstów z lat 1795-1939, Wydawnictwo Dialog, Warszawa.

\section{Conditions for the placement of tourist services in Hutsulshchyna}

In the article the level and conditions of development of tourist services in Hutsulshchyna is considered. The environmental and cultural potential of this mountain territory seems to be entirely unique in the 21 st century. Historical, natural, and cultural conditions, and development of transport infrastructure are important in forming modern basic tourist infrastructure. As for today, tourist infrastructure and services are better developed in the Galicia district of Hutsulshchyna, where first-ever tourist cells were concentrated and a transport system is better developed. The Galicia district of Hutsulshchyna practically provides $70 \%$ of tourist services.

mgr Anna Kibycz

Narodowy Uniwersytet im. Juria Fedkowycza, Czerniowce, Ukraina

Wydział Geograficzny

e-mali: annakib@tlen.pl 